\title{
Introduction from the Soviet Editor
}

IN THE MIDDLE of the nineteenth century, Friedrich Engels wrote that the Pacific Ocean would someday inherit the unifying role that the Mediterranean had played from antiquity through the Middle Ages and that the Atlantic had assumed with the Age of Exploration. Few today would gainsay this prediction. Scientific progress has in our time transformed the Pacific Ocean from a barrier into an avenue between nations and peoples. Across its waters intermingle the interests of socialist, capitalist, and developing countries, among whom stand out the Soviet Union, America, China, and Japan.

Of the multitude of important and difficult tasks facing the peoples and governments of Pacific Basin countries, none is more pressing than that of strengthening peace. It is clear to economists that international trade and long-term economic ties not only reinforce stability and stimulate healthy growth but promote a general atmosphere of trust, mutual respect, and a readiness to seek mutually acceptable solutions to thorny issues. Economic and scientific cooperation, cultural interchange, and international movements of people and information all help dispel prejudices and deepen mutual understanding, whether in the Pacific Basin or in the world as a whole.

In the present unsettled international environment, a widening of regional cooperation in the Pacific Basin is a practicable and effective means to strengthen peace, trust, and security. In the Soviet Union any step toward regional ties is regarded as a positive phenomenon. Nor do we doubt that a majority of Americans share this view.

Two regions with a tremendous economic potential face each other across the North Pacific: the Soviet Far East and the American Far West. It has been a timely and commendable task for fifteen 
Soviet and American scholars to acquaint readers in both countries with these regions. They have united their efforts and come to grips with what in many ways is a unique, pioneering work.

The work seeks to achieve the following four goals. First, it sets out to describe the physical geography of the Soviet Far East and the American Pacific states, juxtaposing their differences and illuminating shared traits of their natural environments. Second, it traces the historical development of each country's economic interests in the Pacific region, with due attention to Russian-American commerce. Third, it measures the scale and analyzes the structure of the Soviet Far Eastern and American Far Western regional economies, relating contemporary trends to roles which these two areas might play in the Pacific Basin. Fourth, it hypothesizes a framework of economic complementarity between our Far East and the American Far West, identifying incentives and constraints bearing upon perspectives for regional economic and scientific cooperation. These issues are, furthermore, addressed here from both Soviet and American points of view.

Although this is not the place to recapitulate arguments and conclusions, I should like nonetheless to make a few observations. In the pages of this collective work, references are made to the lure of the Pacific for Russians and Americans alike. Various motives led them to the shores of this great ocean, not the least of which was the lure of romance. For example, at the beginning of the last century a group of young aristocrats, fated later to participate in the December 1825 uprising in St. Petersburg and to be remembered as Decembrists, decided to establish on Sakhalin a republic modeled after the United States of North America.

More than anything, however, it was economic considerations that attracted Russians to the Far East. Bit by bit inhabitants of Russia's central provinces moved closer to the Pacific in search of land and a better life. Eastward migration assumed a mass character in the middle of the nineteenth century, about the same time that Americans started to settle the Pacific shores of North America in significant numbers. Is there not something symbolic in this coincidence?

The history of Russian-American relations is rich in symbols, and a number of these are treated in this volume. Let us look at an example that does not appear in the text but which in my opinion deserves mention. Mikhail Aleksandrovich Bestuzhev (1800-1871), a Decembrist condemned to permanent exile in the eastern borders of the 
Russian Empire, wound up thirty years later being dispatched by an Amur River trading company to America to purchase paddle wheel steamers. Bad weather prevented Bestuzhev from reaching the United States, but during the course of his attempt he encountered a Cossack battalion descending the Amur, looking for a suitable spot to establish a post on this great river. Bestuzhev advised the battalion commander to locate the post on high ground overlooking the Amur near its junction with the Ussuri River. The commander took this advice. On the site of this post (called Khabarovka), there eventually grew up a city named Khabarovsk, where a good portion of this book was written and translated.

Such examples are good symbols, for they reflect the strivings of peoples of both great countries to build positive relations across the Pacific. This volume contains any number of such historical episodes. Yet with all due respect to our ancestors' deeds, our main focus here is contemporary: to show how the USSR and U.S. might use their geographical propinquity and economic complementarities to activate their relations in the Pacific Basin. An important objective of the Soviet authors has been to highlight the USSR's economic potential in this region, a potential which we feel is not always fully appreciated outside of our country.

Since Soviet rule was established in 1922, the Far East has been transformed into an industrialized region under the leadership of the Communist Party. We feel that the area's potential remains great. Enormous reserves of natural resources await the time when they will be placed at the service of the country and, under favorable international conditions, at the service of other states, notably those of the Pacific Basin.

In realizing this potential a valuable contribution, in our opinion, can be made by regional cooperation with the U.S. Pacific states. Astute observers have identified a dozen fields of knowledge and enterprise where bilateral ties might bring significant results. At the same time, no one can deny that the potential for mutually beneficial interaction between the two regions is hardly being utilized. Completion of the Baikal-Amur Railroad may stimulate new thinking about international economic cooperation in the North Pacific.

Among the contributors to this work are scholars from the USSR Academy of Sciences' Institute of the USA and Canada, the University of California, the University of Washington, and the East-West Center for Scientific and Cultural Interchange in Honolulu. The host institutions are the Institute of Economic Research of the Far 
East Science Center of the USSR Academy of Sciences and the University of Hawaii.

There is no sense in concealing that at times our joint efforts were saddled with complexities. After all, Soviet and American contributors have different ideologies and different methodological approaches to their topics. At the same time, work on this volume brought us closer together. We were animated by a vision of transPacific cooperation and by a determination to convey this vision convincingly to our readers. We were united by respect for the knowledge and professionalism of our colleagues, with whom we shared scientific interests and, in a majority of cases, residence in the Pacific region. Of inestimable utility were the frequent visits to Khabarovsk by the American coeditor, John J. Stephan, and a visit by myself to Honolulu.

The contributors have been united in their opinion that this volume must have a scholarly basis. At the same time, we have tried to make the text accessible to nonspecialist readers in both the Soviet Union and in the United States. To achieve this we stressed conciseness and minimized technical jargon. Conciseness required restricting details and perhaps in some areas depth as well. We ask our readers to forgive this. A hefty book could, of course, be written about the subject covered in each of our chapters.

Parallel editions of this study are appearing in the Soviet Union and in the United States in Russian and English respectively. In general the two editions are identical. However, taking into account differences in the background of Soviet and American readers, some adjustments have been made by mutual agreement of the coeditors. These concern largely the removal or addition of explanatory material. The America edition includes an appendix on cities in the Soviet Far East by V. G. Smoliak. The Soviet edition has an appendix on cities of the American Far West prepared by John B. Richards.

All American chapters were translated into Russian by L. K. Zhukova under the supervision of E. B. Kovrigin. John Stephan has translated all the Soviet contributions. 
Soviet-American

\section{Horizons} on the Pacific 